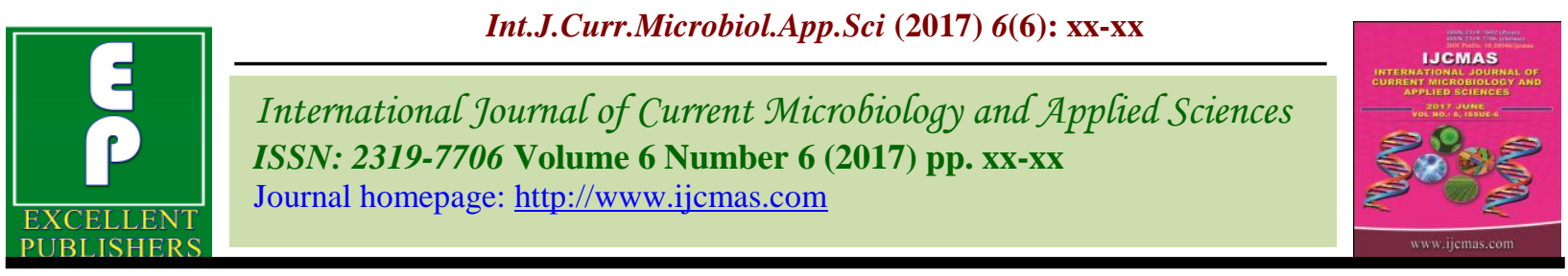

Original Research Article https://doi.org/10.20546/ijcmas.2017.606.185

\title{
GCA and SCA for Fruit Parameters of Okra (Abelmoschus esculentus L. Moench)
}

\author{
Valluru Manju Vani ${ }^{1^{*}}$, B.K. Singh ${ }^{1}$ and S.V.S. Raju ${ }^{2}$ \\ ${ }^{1}$ Department of Horticulture, ${ }^{2}$ Department of Entomology and Agricultural Zoology, Institute of \\ Agricultural Sciences, Banaras Hindu University, Varanasi-221 005, Uttar Pradesh, India \\ *Corresponding author
}

\section{A B S T R A C T}

Combining ability effects of yield and its components in okra were studied through full diallel analysis of $66 \mathrm{~F}_{1}$ hybrids derived by crossing 12 nearly homozygous germplasm

Keywords

Combining ability effects, Full diallel analysis, GCA, Genotypes and SCA.

Article Info

Accepted:

21 May 2017

Available Online:

10 June 2017 lines viz., IC- 45831, IC- 282272, IC- 43733, IC- 43750, IC- 45802, Sel - 4, Pusa Mukhmali, Parbhani Kranti, VRO- 3, Sel - 10, Pusa A-4 and SB -8 and by using Arka Anamika as check. Out of these 12 genotypes, IC-45802, Parbhani Kranti and VRO-3 exhibited highest significant GCA effect for fruit yield per plant $(\mathrm{g})$ and subsequent fruit yield per hectare (q). High GCA effects were attributed to additive or additive $\mathrm{x}$ additive gene effects, which represent the fixable genetic components of variance. Of the top three cross combinations showing positively significant SCA effects for total fruit yield per plant and fruit yield per hectare were, IC-45802 $\times$ SB-8 (49.85), IC-45802 $\times$ Pusa A-4 (48.46) and IC-282272 $\times$ Sel-4 (48.07). The first two crosses involved high $\mathrm{x}$ low general combiners as parents, while the remaining cross involved low $\mathrm{x}$ low general combiners as parents. High performance of these crosses may be attributed to additive $\mathrm{x}$ additive (high $\mathrm{x}$ high), additive $\mathrm{x}$ dominance (high $\mathrm{x}$ low) or dominance $\mathrm{x}$ dominance (low $\mathrm{x}$ low) epistatic interactions. Superiority of the cross combinations involving high $\mathrm{x}$ low or low $\mathrm{x}$ low general combiners as parents may be attributed to the genetic diversity in the form of number of heterozygous loci of the parents involved in the cross combinations

\section{Introduction}

Okra [Abelmoschus esculentus (L.) Moench], also known as lady's finger is one of the most important vegetable crops in the world. It belongs to family Malvaceae having chromosome number $2 n=8 x=72$ or 144 and is polyploidy in nature. It is the preferred vegetable grown extensively in the tropical, subtropical and warm areas of the temperate zones of the world. It has good nutritional value and is the best source of iodine and calcium. In spite of its importance, no major break through has been made towards varietal improvement in this crop and the farmers are still growing their own local varieties or open pollinated varieties. Hence, there is a need for genetic restructuring of this vegetable crop for increasing the productivity.

Hybridization has been the most successful approach in increasing the productivity in vegetable crops. Selection of genetically superior and suitable genotypes is the most important stage from the standpoint of hybridization of vegetable crops in order to 
develop new genotypes having desirable characters. In a systematic breeding programme, it is essential to identify superior parents for hybridization and crosses to expand the genetic variability for selection of superior genotypes (Inamullah et al., 2006). The value of any population depends on its potential per se and it's combining ability in crosses.

Selection of parents on the basis of phenotypic performance alone is not a sound procedure, since phenotypically superior lines may not lead to expected degree of heterosis in $F_{1}$ generation or throw superior transgressive segregants in segregating generations. Thus, any method which would help in choosing desirable parents for hybridization will be important for the vegetable breeders. Combining ability analysis is important to decide parents, crosses and appropriate breeding procedure to be followed to select heterotic $F_{1}$ hybrids or desirable segregants. Diallel analysis is one of the most powerful tools for characterizing the genetic architecture of plant materials and estimating the general combining ability (GCA) of parents and selecting of desirable parents and crosses with high specific combining ability (SCA) for the exploitation of heterosis (Singh et al., 2011). Availability of genetically based variation for yield and its component traits is a prerequisite for the development of new cultivars of okra. To explore the gene pool regarding the presence of variability and its genetic basis, combining ability analysis provides very useful information.

The present investigation was, therefore, undertaken with a set of full-diallel crosses to elicit information about the nature and magnitude of gene action and combining ability effects for yield and its components in okra so as to formulate suitable breeding strategy and isolate potential parents and promising crosses for further exploitation.

\section{Materials and Methods}

The experiments were carried out at the Vegetable Research Farm of the Horticulture Department, Institute of Agricultural Sciences, Banaras Hindu University, Varanasi during 2013 and 2014. The experiment was laid out in Randomized Block Design with three replications. Experimental material for the present investigation was collected from Indian Institute of Vegetable Science (IIVR), Varanasi which comprised of 12 genotypes of A. esculentus belonging to different morphological and productive attributes viz., IC- 45831, IC- 282272, IC- 43733, IC- 43750, IC- 45802, Sel - 4, Pusa Mukhmali, Parbhani Kranti, VRO- 3, Sel - 10, Pusa A-4 and SB 8 and the commercial check used was Arka Anamika.

The present investigation was diallel crossing of 12 parents in all possible combinations excluding reciprocals. The first crop was sown in summer season 2013 with planting material of 12 parents, the second sowing was done in rainy season 2013 with planting material of 12 parents +66 hybrids $\left(\mathrm{F}_{1}\right)$ and the $3^{\text {rd }}$ sowing was done in summer season 2014 with planting material of 12 parents + $66 \mathrm{~F}_{1}+66 \mathrm{~F}_{2}$. The spacing used was $60 \times 30$ $\mathrm{cm}$ (summer crop) and $60 \times 45 \mathrm{~cm}$ (rainy season crop). The combining ability analysis was worked out by the procedure suggested by Griffing's (1956b) Method 2 Model 1 (fixed model). The GCA and SCA were measured for the fruit parameters such as days to $50 \%$ flowering, fruit length $(\mathrm{cm})$, fruit width $(\mathrm{cm})$, fruit weight $(\mathrm{g})$, number of fruits per plant, days to edible fruit maturity, fruit yield per plant (g), fruit yield per hectare (q).

\section{Results and Discussion}

None of the parents or crosses were found to be consistently superior for all the observed traits. 
High GCA effects for some or all of these characters in okra were also reported by Jaiprakashnarayan et al., (2008) and Singh and Kumar (2010). High GCA effects are attributed to additive or additive $\mathrm{x}$ additive gene effects, which represent the fixable genetic components of variance (Griffing, 1956a).

However, it was noted that the possible grouping of top three parents such as IC43733, VRO-3 and IC-282272 were proved to be best general combiner (Table 1) for different specific like days to $50 \%$ flowering; VRO-3, Pusa Makhmali and SB-8 for fruit length (cm); IC-45802, Pusa A-4 and Parbhani Kranti for fruit width $(\mathrm{cm})$; Parbhani Kranti, IC-45802 and VRO-3 for fruit weight (g); IC-45802, Parbhani Kranti and VRO-3 for number of fruits per plant; IC-45831, IC43750 and IC-282272 for days to edible fruit maturity; IC-45802, Parbhani Kranti and VRO-3 for fruit yield per plant (g) and IC45802, Parbhani Kranti and VRO-3 for fruit yield per hectare $(\mathrm{q})$.

These parental lines with high GCA effects may be used in a multiple crossing programme for isolating desirable lines in okra. The selected lines from such multiple crosses could be released as conventional varieties or used as improved parents for $\mathrm{F}_{1}$ hybrid production.

Similar reports have been also reported by Singh et al., (2012) and Parmar et al., (2012). The significant and desirable crosses in order of merit were IC-45831 $\times$ Pusa Mukhmali,IC$45831 \times$ Parbhani Kranti and Pusa Mukhmali $\times$ Sel-10 for days to $50 \%$ flowering; Parbhani Kranti $\times$ Sel-10, VRO-3 $\times$ SB-8 and Pusa Makhmali $\times$ Sel-10 for fruit length $(\mathrm{cm})$; Pusa Makhmali $\times$ Parbhani Kranti, IC-45831 ×
Pusa Makhmali and IC-43733 $\times$ Pusa A-4 for fruit width $(\mathrm{cm})$; IC-45802 $\times$ Pusa A-4, IC$282272 \times$ Sel-4 and Pusa A-4 $\times$ SB- 8 for fruit weight $(\mathrm{g})$; IC-45831 $\times$ IC-43733, IC-43750 $\times$ Sel-4 and IC-45802 $\times$ VRO-3 for number of fruits per plant; IC-45802 $\times$ Pusa A-4, IC$45831 \times$ Parbhani Kranti and IC-282272 × Pusa A-4 for days to edible fruit maturity; IC$45802 \times$ SB-8, IC-45802 $\times$ Pusa A-4 and IC$282272 \times$ Sel-4 for fruit yield per plant $(\mathrm{g})$; IC-45802 $\times$ SB-8, IC-45802 $\times$ Pusa A-4 and IC-282272 $\times$ Sel-4 for fruit yield per hectare (q) were showed significant and desirable specific combiners.

Similarly, a critical combination of per se performance of three best crosses for the eight characters also revealed that there is no direct relationship between the per se performance of crosses and their parents. Similar findings have also been reported by Kumar et al., (2014) and Singh et al., (2012).

Significant SCA effects were observed for all the traits. In the present experimentation in general, a relatively higher magnitude of SCA effects were observed in many crosses for fruit yield per plant and fruit yield per hectare (Table 2), which may probably be due to the formation of superior gene recombinations (Singh et al., 2011).

The negative SCA effects observed in some of the crosses for different characters might be due to the presence of unfavourable gene combinations in the parents for the respective traits.

Of the various high specific combiners identified for, the parental lines of the various cross combinations displayed very critical trends in their GCA effects for different characters. 
Table.1 Estimation of general combining ability (GCA) effect of 12 parents for 8 characters of okra

\begin{tabular}{|c|c|c|c|c|c|c|c|c|}
\hline Genotype & $\begin{array}{c}\text { Days to } \\
50 \% \\
\text { flowering }\end{array}$ & $\begin{array}{c}\text { Fruit } \\
\text { length } \\
(\mathrm{cm})\end{array}$ & $\begin{array}{c}\text { Fruit } \\
\text { width }(\mathbf{c m})\end{array}$ & $\begin{array}{c}\text { Fruit } \\
\text { weight }(\mathrm{g})\end{array}$ & $\begin{array}{c}\text { Number of } \\
\text { fruits per } \\
\text { plant }\end{array}$ & $\begin{array}{c}\text { Days to } \\
\text { edible } \\
\text { fruit } \\
\text { maturity }\end{array}$ & $\begin{array}{c}\text { Fruit yield } \\
\text { per plant } \\
\text { (g) }\end{array}$ & $\begin{array}{r}\text { Fruit } \\
\text { yield/ ha }\end{array}$ \\
\hline IC-45831 & $0.39 *$ & -0.17 & 0.01 & $-1.34 * *$ & -0.01 & $-0.06 *$ & $-16.36 * *$ & -12.12 \\
\hline IC-282272 & -0.17 & -0.13 & $-0.16^{* *}$ & $-1.15 * *$ & -0.03 & -0.01 & $-15.13 * *$ & -11.21 \\
\hline IC-43733 & $-0.32 *$ & 0.14 & 0.01 & $-0.52 *$ & $-0.49 *$ & 0.00 & $-17.14 * *$ & -12.70 \\
\hline IC-43750 & -0.03 & -0.01 & -0.01 & $-0.56^{*}$ & 0.01 & -0.02 & $-6.99 *$ & -5.18 \\
\hline IC-45802 & 0.00 & $0.42 *$ & $0.12 * *$ & $1.01 * *$ & $0.85 * *$ & 0.02 & $33.27 * *$ & 24.65 \\
\hline Sel-4 & 0.01 & -0.15 & $-0.05 * *$ & -0.38 & -0.10 & -0.01 & $-7.17 *$ & -5.31 \\
\hline PusaMakhmali & -0.02 & $0.33 *$ & -0.02 & $0.50 *$ & -0.21 & $0.05^{*}$ & 0.54 & 0.40 \\
\hline $\begin{array}{l}\text { ParbhaniKrant } \\
\text { i }\end{array}$ & 0.03 & -0.03 & $0.06^{* *}$ & $1.42 * *$ & 0.12 & 0.00 & $20.92 * *$ & 15.50 \\
\hline VRO-3 & -0.26 & $-0.59 * *$ & -0.02 & $0.66 *$ & 0.04 & 0.02 & $8.72 * *$ & 6.46 \\
\hline Sel-10 & 0.14 & 0.04 & $-0.07 * *$ & -0.02 & -0.19 & 0.01 & $-5.16^{*}$ & -3.82 \\
\hline Pusa A-4 & 0.00 & -0.03 & $0.07 * *$ & 0.05 & 0.01 & 0.01 & 0.74 & 0.55 \\
\hline SB-8 & 0.24 & 0.19 & $0.05 * *$ & 0.32 & -0.01 & -0.02 & 3.75 & 2.78 \\
\hline & \multicolumn{5}{|c|}{ CD Comparisons for GCA } & & & \\
\hline Gi<> 0 at $95 \%$ & \begin{tabular}{l|l}
0.35 & \\
\end{tabular} & 0.35 & 0.03 & 0.54 & 0.32 & 0.04 & 5.08 & 0.31 \\
\hline $\mathrm{Gi}<>0$ at $99 \%$ & 0.49 & 0.49 & 0.04 & 0.76 & 0.46 & 0.06 & 7.17 & 0.44 \\
\hline Gi--Gj at $95 \%$ & 0.51 & 0.51 & 0.05 & 0.80 & 0.48 & 0.06 & 7.50 & 0.46 \\
\hline Gi--Gj at $99 \%$ & 0.72 & 0.72 & 0.07 & 1.12 & 0.68 & 0.08 & 10.59 & 0.65 \\
\hline
\end{tabular}

Table.2 Estimation of specific combining ability (SCA) effect of 66 $\mathrm{F}_{1}$ hybrids for 8 characters of okra

\begin{tabular}{|c|c|c|c|c|c|c|c|c|}
\hline Cross & $\begin{array}{c}\text { Days to } \\
50 \% \\
\text { flowering }\end{array}$ & $\begin{array}{c}\text { Fruit } \\
\text { length } \\
(\mathrm{cm})\end{array}$ & $\begin{array}{c}\text { Fruit } \\
\text { width } \\
(\mathrm{cm})\end{array}$ & $\begin{array}{c}\text { Fruit } \\
\text { weight } \\
\text { (g) }\end{array}$ & $\begin{array}{c}\text { Number } \\
\text { of fruits } \\
\text { per } \\
\text { plant }\end{array}$ & $\begin{array}{c}\text { Days to } \\
\text { edible } \\
\text { fruit } \\
\text { maturity }\end{array}$ & $\begin{array}{c}\text { Fruit } \\
\text { yield per } \\
\text { plant (g) }\end{array}$ & $\begin{array}{c}\text { Fruit } \\
\text { yield per } \\
\text { ha (q) }\end{array}$ \\
\hline IC-45831×IC-282272 & -0.32 & -0.11 & $0.12 *$ & $2.41 *$ & -0.50 & 0.06 & $17.99 *$ & $13.32 *$ \\
\hline IC-45831×IC-43733 & -0.44 & -0.27 & 0.03 & 0.75 & $1.55 * *$ & 0.05 & $40.54 * *$ & $30.03 * *$ \\
\hline IC-45831 ×IC-43750 & -1.06 & 0.11 & 0.09 & 1.39 & 0.05 & 0.11 & $17.81^{*}$ & $13.20^{*}$ \\
\hline IC-45831 $\times$ IC-45802 & -0.42 & 0.40 & $0.16^{*}$ & 0.36 & $1.15^{*}$ & 0.00 & $27.92 *$ & $20.68^{*}$ \\
\hline IC-45831 $\times$ Sel-4 & -0.03 & -0.43 & 0.06 & -0.34 & $-1.14 *$ & $0.20 *$ & $-29.37 * *$ & $-21.76 * *$ \\
\hline IC-45831×Pusa Makhmali & $-1.27 *$ & 0.56 & $0.21 * *$ & -0.38 & -0.06 & -0.07 & -6.02 & -4.46 \\
\hline IC-45831×Parbhani Kranti & $-1.19 *$ & -1.04 & $-0.18^{* *}$ & 0.75 & 0.28 & $-0.15^{*}$ & 14.49 & 10.74 \\
\hline IC-45831×VRO-3 & 0.10 & 0.61 & $-0.15^{*}$ & -0.64 & $1.15^{*}$ & 0.03 & 15.24 & 11.29 \\
\hline IC-45831×Sel-10 & 1.03 & 0.38 & -0.08 & 0.20 & $\begin{array}{l}-0.81 \\
\end{array}$ & 0.08 & -15.83 & -11.73 \\
\hline IC-45831 ×Pusa A-4 & -0.16 & -0.24 & -0.09 & 1.14 & 1.05 & 0.11 & $36.72 * *$ & $27.20^{* *}$ \\
\hline IC-45831×SB-8 & 1.14 & -0.99 & $-0.27 * *$ & 0.91 & 1.00 & 0.10 & $33.32 * *$ & $24.68^{* *}$ \\
\hline IC-282272×IC-43733 & -0.41 & 0.65 & -0.01 & 1.34 & 0.77 & 0.00 & $32.82 * *$ & $24.32 * *$ \\
\hline IC-282272xIC-43750 & -0.83 & -0.55 & -0.01 & 1.52 & 0.28 & 0.12 & $24.99^{*}$ & $18.51^{*}$ \\
\hline IC-282272 $\times I C-45802$ & 0.34 & 0.24 & -0.06 & -0.41 & -0.09 & 0.09 & -10.16 & -7.52 \\
\hline IC-282272×Sel-4 & $-1.14 *$ & -0.35 & -0.04 & $3.11 * *$ & 0.39 & -0.02 & $48.07 * *$ & $35.61 * *$ \\
\hline IC-282272×Pusa Makhmali & 0.36 & $-1.14 *$ & 0.06 & -0.67 & 0.83 & $\begin{array}{c}-0.08 \\
\end{array}$ & 9.19 & 6.81 \\
\hline IC-282272×Parbhani Kranti & 0.24 & 0.09 & -0.02 & $-2.16^{*}$ & -0.10 & 0.03 & $-30.99 * *$ & $-22.96 * *$ \\
\hline IC-282272×VRO-3 & -0.80 & 0.03 & 0.07 & 0.39 & 0.61 & 0.01 & $18.76^{*}$ & $13.89^{*}$ \\
\hline IC-282272×Sel-10 & 0.73 & -0.15 & -0.08 & -0.97 & 0.28 & -0.07 & -7.47 & -5.53 \\
\hline IC-282272×Pusa A-4 & -1.00 & 1.11 & -0.05 & -0.02 & -0.13 & $-0.14 *$ & -3.77 & -2.79 \\
\hline IC-282272×SB-8 & -0.03 & -0.96 & $-0.18^{* *}$ & 1.16 & 0.63 & $-0.14 *$ & $28.20 *$ & $20.89^{*}$ \\
\hline IC-43733×IC-43750 & -0.61 & 0.71 & -0.06 & 0.60 & 0.20 & 0.01 & 11.27 & 8.35 \\
\hline IC-43733×IC-45802 & -0.31 & 0.09 & $0.11^{*}$ & 1.50 & -0.04 & 0.07 & $17.87 *$ & $13.24 *$ \\
\hline
\end{tabular}




\begin{tabular}{|c|c|c|c|c|c|c|c|c|}
\hline IC-43733 $\times$ Sel-4 & -0.32 & -0.75 & -0.07 & -0.57 & 0.91 & -0.10 & 11.68 & 8.65 \\
\hline IC-43733×Pusa Makhmali & -0.82 & 1.11 & $-0.13 *$ & 0.98 & -0.11 & $-0.13 *$ & 9.48 & 7.02 \\
\hline IC-43733×Parbhani Kranti & -0.54 & -0.19 & -0.10 & 0.58 & -0.18 & 0.02 & 2.28 & 1.69 \\
\hline IC-43733×VRO-3 & 0.35 & 0.09 & 0.07 & -0.20 & -0.70 & $\begin{array}{l}-0.03 \\
\end{array}$ & $-19.17^{*}$ & $-14.20 *$ \\
\hline IC-43733×Sel-10 & 1.01 & -0.09 & -0.09 & $1.93^{*}$ & -0.07 & -0.02 & $20.00 *$ & $14.82 *$ \\
\hline IC-43733×Pusa A-4 & 0.42 & -0.76 & $0.21 * *$ & -0.25 & 0.00 & -0.05 & -3.97 & -2.94 \\
\hline IC-43733×SB-8 & -0.21 & 0.33 & -0.01 & 0.35 & 0.41 & 0.01 & 12.68 & 9.39 \\
\hline IC-43750xIC-45802 & -1.00 & 0.61 & $0.17 *$ & -0.22 & -0.60 & 0.03 & $-19.26^{*}$ & $-14.26^{*}$ \\
\hline IC-43750×Sel-4 & 0.79 & 0.44 & 0.09 & 0.11 & $1.28^{*}$ & 0.03 & $28.78^{*}$ & $21.32 *$ \\
\hline IC-43750×Pusa Makhmali & 0.15 & -0.75 & 0.09 & -0.74 & 0.66 & 0.06 & 5.59 & 4.14 \\
\hline IC-43750×Parbhani Kranti & -0.16 & 0.13 & -0.07 & -0.73 & 0.19 & -0.02 & -5.37 & -3.98 \\
\hline IC-43750×VRO-3 & -0.88 & 0.12 & 0.06 & -0.64 & 0.00 & -0.04 & -7.98 & -5.91 \\
\hline IC-43750×Sel-10 & -0.88 & -0.32 & 0.05 & 0.80 & 0.50 & -0.06 & $21.61 *$ & $16.00^{*}$ \\
\hline IC-43750×Pusa A-4 & -0.60 & 0.52 & -0.07 & $1.91 *$ & -0.27 & 0.07 & $17.93 *$ & $13.28 *$ \\
\hline IC-43750×SB-8 & 0.76 & -0.33 & $-0.17 *$ & $1.82 *$ & -0.08 & 0.00 & $21.97 *$ & $16.27 *$ \\
\hline IC-45802 $\times$ Sel-4 & -0.84 & 0.23 & $0.15^{*}$ & 0.83 & 0.17 & 0.09 & 14.84 & 10.99 \\
\hline IC-45802×Pusa Makhmali & -0.94 & -0.45 & -0.06 & -1.29 & 0.88 & -0.01 & 1.99 & 1.47 \\
\hline IC-45802 $\times$ Parbhani Kranti & 0.54 & -0.29 & $-0.24 * *$ & -0.79 & 0.86 & 0.07 & 11.72 & 8.68 \\
\hline IC-45802×VRO-3 & -0.50 & -0.44 & $-0.24 * *$ & -0.69 & 1.23 & -0.11 & $20.41 *$ & $15.12 *$ \\
\hline IC-45802×Sel-10 & 0.36 & $-1.43 *$ & $-0.14^{*}$ & 0.05 & 0.26 & 0.04 & 6.44 & 4.77 \\
\hline IC-45802 $\times$ Pusa A-4 & -0.63 & 0.53 & 0.04 & $3.36 * *$ & 0.06 & $-0.16^{*}$ & $48.46 * *$ & $35.89 * *$ \\
\hline IC-45802 $\times$ SB-8 & -0.80 & 0.58 & 0.04 & $2.33^{*}$ & 0.61 & -0.04 & $49.85^{* *}$ & $36.92 * *$ \\
\hline Sel-4×Pusa Makhmali & -0.89 & 0.17 & -0.08 & 0.01 & 0.90 & -0.05 & $21.28^{*}$ & $15.76^{*}$ \\
\hline Sel-4×Parbhani Kranti & -0.73 & 0.33 & -0.07 & -1.13 & 0.10 & -0.03 & -12.51 & -9.26 \\
\hline Sel-4×VRO-3 & -1.11 & -0.21 & -0.09 & 0.72 & -0.89 & -0.08 & -11.71 & -8.68 \\
\hline Sel-4×Sel-10 & -0.78 & 0.15 & -0.05 & -0.21 & 0.48 & 0.03 & 7.72 & 5.72 \\
\hline Sel-4×Pusa A-4 & -0.91 & 0.35 & -0.09 & 0.70 & -0.26 & -0.07 & 3.53 & 2.61 \\
\hline Sel-4×SB-8 & -0.61 & 0.23 & -0.04 & -0.04 & -0.31 & 0.02 & -8.56 & -6.34 \\
\hline PusaMakhmali×ParbhaniKranti & -0.84 & 0.42 & $0.25 * *$ & -1.16 & -0.05 & 0.00 & -16.22 & -12.01 \\
\hline Pusa MakhmalixVRO-3 & 0.38 & 1.09 & -0.08 & 0.02 & -0.38 & -0.05 & -7.05 & -5.22 \\
\hline Pusa Makhmali×Sel-10 & $-1.15^{*}$ & 1.14 & 0.01 & -0.59 & -0.34 & -0.03 & -14.62 & -10.83 \\
\hline PusaMakhmalixPusa A-4 & -0.01 & 0.93 & $-0.19 * *$ & 0.55 & 0.12 & $0.13^{*}$ & 10.75 & 7.96 \\
\hline Pusa Makhmali×SB-8 & -0.71 & 0.64 & 0.02 & 0.14 & -0.86 & -0.04 & $-18.01 *$ & $-13.35^{*}$ \\
\hline Parbhani KrantiixVRO-3 & -0.33 & 0.49 & 0.10 & $-1.81 *$ & 0.16 & -0.06 & $-19.13 *$ & $-14.17 *$ \\
\hline Parbhani Krantii×Sel-10 & -0.60 & $1.49^{*}$ & 0.07 & -1.23 & 0.40 & -0.09 & -5.43 & -4.02 \\
\hline ParbhaniKrantiixPusa A-4 & -0.13 & -0.30 & $0.14 *$ & -0.55 & -0.24 & 0.01 & -12.53 & -9.28 \\
\hline Parbhani Krantii×SB-8 & -0.90 & -0.29 & 0.06 & -1.26 & -0.66 & -0.09 & $-31.07 * *$ & $-23.01 * * *$ \\
\hline VRO-3×Sel-10 & -0.38 & 0.72 & $0.12 *$ & 0.62 & 0.07 & 0.06 & 10.11 & 7.49 \\
\hline VRO-3×Pusa A-4 & -0.38 & 0.62 & 0.02 & -0.26 & 0.33 & -0.10 & 5.03 & 3.72 \\
\hline VRO-3×SB-8 & -0.88 & $1.21 *$ & $0.17 *$ & -0.46 & 0.08 & 0.06 & -3.91 & -2.90 \\
\hline Sel-10×Pusa A-4 & -0.98 & 0.07 & 0.04 & -0.27 & -0.10 & $0.14 *$ & -5.61 & -4.16 \\
\hline Sel-10×SB-8 & -1.08 & 0.64 & 0.06 & 1.20 & -0.21 & -0.03 & 10.31 & 7.64 \\
\hline Pusa A-4×SB-8 & -0.07 & 0.17 & $0.15^{*}$ & $3.01 *$ & -0.49 & 0.00 & $27.31 *$ & $20.23^{*}$ \\
\hline \multicolumn{9}{|l|}{ C. D. Comparisons } \\
\hline Sij<>> 0 at $95 \%$ & 1.14 & 1.14 & 0.10 & 1.78 & 1.07 & 0.13 & 16.78 & 12.43 \\
\hline Sij<> 0 at $99 \%$ & 1.52 & 1.52 & 0.14 & 2.37 & 1.43 & 0.17 & 22.30 & 16.52 \\
\hline Sij--Sik at $95 \%$ & 1.67 & 1.67 & 0.15 & 2.61 & 1.57 & 0.19 & 24.54 & 18.18 \\
\hline Sij--Sik at $99 \%$ & 2.22 & 2.22 & 0.20 & 3.46 & 2.08 & 0.25 & 32.61 & 24.16 \\
\hline Sij--Skl at $95 \%$ & 1.61 & 1.61 & 0.15 & 2.50 & 1.51 & 0.18 & 23.58 & 17.47 \\
\hline Sij--Skl at 99\% & 2.13 & 2.13 & 0.19 & 3.33 & 2.00 & 0.24 & 31.33 & 23.21 \\
\hline
\end{tabular}

Of the top five cross combinations showing positively significant SCA effects for total yield per plant were IC-45802 × SB-8 (49.85), IC-45802 × Pusa A-4 (48.46), IC-282272 $\times$
Sel-4 (48.07), IC-45831 $\times \quad$ IC-43733 (40.54)and IC-45831 × Pusa A-4 (36.72). The first two crosses involved high $x$ low general combiners as parents, while the remaining 
three crosses involved low $\mathrm{x}$ low general combiners as parents. For other yield associated traits also, the top five cross combinations exhibiting significant SCA effects in desirable direction involved high $\mathrm{x}$ high, high $\mathrm{x}$ low and low $\mathrm{x}$ low general combiners as parents. From the perusal of the GCA status of the parents of high specific combiners for various traits, it is evident that the high specific combiners involved high $\mathrm{x}$ high, high $\mathrm{x}$ low and $\mathrm{x}$ low general combiners as parents, indicating that high specific combiners are not only obtained from the combination of high $\mathrm{x}$ high general combiners but also obtained from the combination of high $\mathrm{x}$ low and low $\mathrm{x}$ low general combiners. Thus, high GCA effects of the parents, therefore, do not seem to be a reliable criterion for the prediction of high SCA effects. High performance of these crosses may be attributed to additive $\mathrm{x}$ additive (high $\mathrm{x}$ high), additive $\mathrm{x}$ dominance (high $\mathrm{x}$ low) or dominance $\mathrm{x}$ dominance (low $\mathrm{x}$ low) epistatic interactions (Rewale et al., 2003). Superiority of the cross combinations involving high $\mathrm{x}$ low or low $\mathrm{x}$ low general combiners as parents may be attributed to the genetic diversity in the form of number of heterozygous loci of the parents involved in the cross combinations. In some of the characters studied, parents with high GCA effects produced hybrids with low SCA effects. This may be due to the lack of complementation of the parental genes. On the other hand, parents with low GCA effects produced hybrids with high SCA effects which can be attributed to complementary gene action. Of the top five promising specific combiners identified for total yield per plant only two crosses had one of the parents with high GCA effects. These could be utilized in recombination breeding with single plant selection in the passing generations to capitalize the additive gene action to develop lines or varieties. Ahmed et al., (1997) also noted that when parents with high and low GCA effects were involved in across, the parent with low GCA effect could throw up desirable transgressive segregates giving rise to a desirable population. This is only possible if the additive genetic system present in the good general combiner and the complementary epistatic effect present in the crosses that could act in a complementary fashion to maximize desirable plant attributes and could be exploited for further breeding.

\section{Acknowledgement}

The corresponding author is highly grateful to the Department of Science and Technology for providing financial assistance in the form of INSPIRE Fellowship for the present study.

\section{References}

Ahmed, N., Hakim, M.A. and Zargar, G.H. 1997. Combining ability studies in okra [Abelmoschus esculentus (L.) Moench]. Veg. Sci., 24(2): 95-98.

Griffing, B. 1956a. Concept of general and specific combining ability in relation to diallel crossing system. Aus. J. Biol. Sci., 9: 463-493.

Griffing, B. 1956b. A generalized treatment of the use of diallel crosses in quantitative inheritance. Heredity, 10: 31-50.

Inamullah, Ahmed, H., Muhammad, F., Sirajuddin, Hassan, G. and Gul, R. 2006. Evaluation of heterotic and heterobeltiotic potential of wheat genotype for improved yield. Pak. J. Bot., 38(4): 1159-1168.

Jaiprakashnarayan, R.P., Prashanth, S.J., Mulge, R. and Madalageri, M.B. 2008. Study on heterosis and combining ability for earliness and yield parameters in okra (Abelmoschus esculentus (L.) Moench). Asian J. Horticult., 3(1): 136-141. 
Kumar, S., Singh, A.K., Das, R., Datta, S. and Arya, K. 2014. Combining ability and its relationship with gene action in okra [Abelmoschus esculentus (L.) Moench]. J. Crop Weed, 10(1): 82-92.

Parmar, S.K., Tank, C.J. and Bhadauria, H.S. 2012. Study of quantitative traits in okra [Abelmoschusesculentus (L.) Moench] by using half diallel analysis. Res. Crops, 13(2):773-775.

Rewale, V.S., and Bendale, V.M., Bhave, S.G., Madav, R.R. and Jadhav, B.B. 2003. Combining ability of yield and yield components in okra. $J$. Maharastra Agril. Univ., 28: 244-246.

Singh, B. and Kumar, V. 2010. Studies on combining ability analysis in okra. Ind. J. Hort., 67(Special Issue):154-159.

Singh, B., Kumar, M. and Naresh, R.K. 2012. Combining ability analysis of yield and its components in okra. Ind. J. Hort., 69(2):195-199.

Singh, B., Singh, S.K., Singh, K.V. 2011. Study on combining ability in okra (Abelmoschus esculentus L. Moench). Progressive Agri., 11(2): 361-363.

\section{How to cite this article:}

Valluru Manju Vani, B.K. Singh and Raju, S.V.S. 2017. GCA and SCA for fruit parameters of okra (Abelmoschus esculentus L. Moench). Int.J.Curr.Microbiol.App.Sci. 6(6): 1576-1582. doi: https://doi.org/10.20546/ijcmas.2017.606.185 